\title{
Beacon of Liberty: Role Conceptions, Crises and Stability in Georgia's Foreign Policy, 2004-2012
}

\author{
Niklas Nilsson \\ Uppsala: Uppsala University 2015 \\ 280 sider. ISBN 9789155492748
}

Anmeldt af Anders Wivel [professor MSO, Institut for Statskundskab, Københavns Universitet, Danmark, aw@ifs.ku.dk]

Det postsovjetiske område er blevet genstand for fornyet politisk interesse i Europa og USA gennem de senere år. Mens området (undtagen Baltikum) næsten blev glemt $\mathrm{i}$ euforien over Den Kolde Krigs afslutning og i det efterfølgende arbejde med at udvide EU og NATO med en række central- og østeuropæiske lande, og kun spillede en birolle i efterspillet til terrorangrebene på New York og Washington i 2001, så har de senere års assertive russiske udenrigspolitik - og ikke mindst konflikterne i Georgien og Ukraine - sat fokus på de tidligere sovjetrepublikker, som ligger tættest på det fortsat fredelige og institutionaliserede euro-atlantiske område.

I denne udvikling har særligt Georgien været genstand for opmærksomhed; både fra de politiske beslutningstagere i USA og Rusland og for en række akademiske analyser af georgisk udenrigspolitik efter den såkaldte »rose-revolution« i 2003. Georgien har påkaldt sig særlig interesse af flere årsager. Landet blev i 2005 udråbt til en ledestjerne for frihed (»beacon of liberty«) af den daværende amerikanske præsident George W. Bush under hans besøg i Tbilisi. Det var målet for betydelig amerikansk opmærksomhed og støtte (økonomisk og politisk) i de år, hvor afgørende neokonservativ indflydelse på amerikansk udenrigspolitik betød et fokus på udbredelse af liberalt demokrati. Her spillede Georgien en særlig rolle på grund af sin fredelige revolution, hvor en ny generation af vestligt inspirerede politikere reformerede det georgiske samfund politisk og økonomisk og knyttede tætte bånd til Vesten ikke mindst USA. Samtidig - og delvis som en følge heraf, ikke mindst i relation til det georgiske ønske om NATO-medlemskab - blev Georgien testcase for en ny russisk udenrigspolitik, der i et direkte opgør med den amerikanske verdensorden hævdede sin interessesfære i det postsovjetiske område.

Niklas Nilssons grundige og velskrevne Beacon of Liberty: Role Conceptions, Crises and Stability in Georgia's Foreign Policy, 2004-2012 forklarer, hvordan Georgiens udenrigspolitik udfoldede sig i dette samspil mellem indenrigspolitisk revolution efterfulgt af reformer og geopoliske vilkår og stormagtsinteresser. Bogen, som er en ph.d.-afhandling udarbejdet ved Södertörns Högskola og Uppsala Universitet, fokuserer i særlig grad på, at forklare den bemærkelsesværdige kontinuitet i georgisk udenrigspolitik i perioden. Georgiske beslutningstagere argumenterede fra begyndelsen 
af perioden for, at Georgiens legitimitet som fuldgyldig vestlig alliereret var baseret på dels demokratisering af det georgiske samfund og dels et georgisk netto-bidrag til euro-atlantisk sikkerhed. Denne kurs blev fastholdt, selv om demokratisering i nogen grad blev afløst af modernisering, der var flere eksempler på anti-demokratiske tiltag fra den politiske ledelse - ikke mindst i forbindelse med voldsomme demonstrationer i november 2007, og selv om konflikten med Rusland over Abkhasien og Sydossetien, der i august 2008 udmøntedes i en krig mellem Georgien og Rusland, satte spørgsmålstegn ved det georgiske netto-bidrag til euro-atlantisk sikkerhed.

Nilsson tolker den overraskende stabilitet i lyset af denne udvikling med udgangspunkt i de georgiske beslutningstageres rolleopfattelser, og hvordan de gennem disse roller forholder sig til krise og forandring. I et samspil mellem eksterne (særligt amerikanske) forventninger til georgisk udenrigspolitik og de georgiske beslutningstageres svar på disse forventninger i kontekst af både deres egen opfattelse af Georgien som et moderniserende, europæisk land og de forventede gevinster ved denne position, formuleredes en udenrigspolitik, som både var stabil og præget af indre modsætninger. Både rollen som »ledestjerne for frihed « og netto-bidragyder til euro-atlantisk sikkerhed repræsenterede operationaliseringer af denne opfattelse af den rigtige vej for Georgien, samtidig med at et væsentligt middel til at nå målet om et moderne europæisk land ville være støtte fra USA. Da det efter krigen med Rusland blev tydeligt, at USA var mindre villig end hidtil til at støtte georgisk medlemskab af NATO, fastholdtes den udenrigspolitiske kurs, der nu var indlejret $i$ et sæt gensidige forventninger fra det georgiske og amerikanske lederskab om, hvilken rolle Georgien kunne og burde spille i den amerikanske verdensorden. Det blev i stigende grad umuligt for præsident Saakashvili og hans politiske allierede at forestille sig en anden vej for Georgien.

Beacon of Liberty præsenterer en overbevisende, veldokumenteret og spændende analyse af georgisk udenrigspolitik, og bogen fortjener en stor læserskare. Som ved alle videnskabelige værker er der dog også svagheder i Nilssons studie. Det er uklart i hvilket omfang de identificerede roller er koblet til specifikke beslutningstagere eller et specifikt segment af den politiske elite, eller om de udtrykker en mere grundlæggende politisk eller strategisk kultur. Dermed bliver det også uklart i hvor høj grad disse roller er foranderlige, og hvilke faktorer, der vil kunne medføre udenrigspolitisk forandring. Mere grundlæggende kan man diskutere, hvad der konstituerer udenrigspolitisk forandring og om politikforandring altid vil være koblet til rolleforandring. Nilssons studie viser netop, at der er betydeligt rum for fortolkning og rationalisering indenfor de enkelte roller, men hvis det er tilfældet, hvornår bliver det så meningsløst at tale om en fastholdelse af rollen, og hvornår er den gennem nyfortolkninger blevet til en ny rolle, der kan tjene som udgangspunkt for politikken? Nilssons studie rummer ikke klare svar på disse problematikker.

Nilssons studie er den hidtil grundigste analyse af, hvordan georgisk udenrigspolitik formuleredes og blev udfoldet i samspil med amerikanske forventninger i en central periode $\mathrm{i}$ landets historie. Det er samtidig en spændende og original analyse af udenrigspolitisk kontinuitet $\mathrm{i}$ en forandringstid. Afhandlingen er på den baggrund central for alle, som beskæftiger sig med georgisk udenrigspolitik, og den er samtidig relevant for interesserede i udenrigspolitik og postsovjetisk politik mere generelt. 